\begin{tabular}{rr} 
çağdaş & Yaratıcı Drama Dergisi 2015, 10(1), 117-134 \\
drama & www.yader.org \\
\hline
\end{tabular}

\title{
Bir Anadil Olarak Dans ve Şarkı \\ Okul Öncesinde Drama Çalışmalarında Geleneksel Masallar, Çocuk Tekerlemeleri, Şarkılar ve Oyunlar
}

\author{
Tamás Korzenszky ${ }^{1}$
}

\begin{tabular}{|c|c|}
\hline Makale Bilgisi & Öz \\
\hline DOI: $10.21612 /$ yader.2015.011 & \multirow[b]{2}{*}{$\begin{array}{l}\text { Geleneksel çocuk tekerlemeleri, çocuk şarkıları ve şarkılı oyunlar yirminci yüzyılın } \\
\text { ortalarından beri Macar okul öncesi eğitiminde, müzikte ve dans pedagojisinde etkili, } \\
\text { vazgeçilmez ve yaşa uygun araçlar olarak kullanılmaktadır. Çocuk tekerlemelerinin, } \\
\text { çocuk şarkıların ve şarkılı oyunların çok eskilere dayandığı ve tarih öncesi kültürel } \\
\text { mirasın bir katmanı olduğu etnograflar tarafindan ortaya çıkarılmıştır. Hareketlerle } \\
\text { iç içe geçmişşarkılar, izole olmuş hareketlerden arınmış olan şarkllardan çok daha } \\
\text { karmaşı ve eski fenomenlerdir. Bunları sık sık geleneksel yetişkin ritüellerinde ve } \\
\text { örflerinde görürüz. Orijinal anlamlarıyla birlikte belirli olaylarda, bazı metinlerde } \\
\text { karşımıza çıkarlar. Bu yüzden anlaşılmaz gibi görünürler ancak hâlâ oldukça iyi } \\
\text { bilinirler ve popülerlerdir. }\end{array}$} \\
\hline $\begin{array}{l}\text { Anahtar Sözcükler } \\
\text { Macar okul öncesi eğitimi } \\
\text { Şarkllı oyunlar } \\
\text { Geleneksel çocuk tekerlemeleri } \\
\text { Geleneksel çocuk tekerlemeleri } \\
\text { Geleneksel masallar }\end{array}$ & \\
\hline & $\begin{array}{l}\text { Etnografların çalışmalarının kanıtlarına dayanarak bu tekerleme ve şarkılı } \\
\text { oyunların kökenini bulmak için izleri sürülüp orijinal anlamlarına ve işlevlerine } \\
\text { ulaşılabilir. Halk şiirinin bu küçük ürünleri birkaç kırık ayna parçası, birkaç tane } \\
\text { dağılmış puzzle parçası gibi girift sembollerle ya da masalların içine girerek ve } \\
\text { masallarla örülü bir hikâye olan Campbell'ın "Kahramanın Sonsuz Yolculuğu" } \\
\text { kitabı gibi tematik şeylerle yeniden kurulup anlamlandırılabilir. Bağlamlanabilme } \\
\text { özelliklerinden ötürü halk şiirinin bu küçük ürünleri daha yalınlaştırılarak çocuklar } \\
\text { için daha anlaşılabilir hale getirilebilir. }\end{array}$ \\
\hline
\end{tabular}

\section{Singing and Dance as Our Mother Tongue; Traditional Nursery Rhymes and Singing Games in Preschool Fairy Tale Drama}

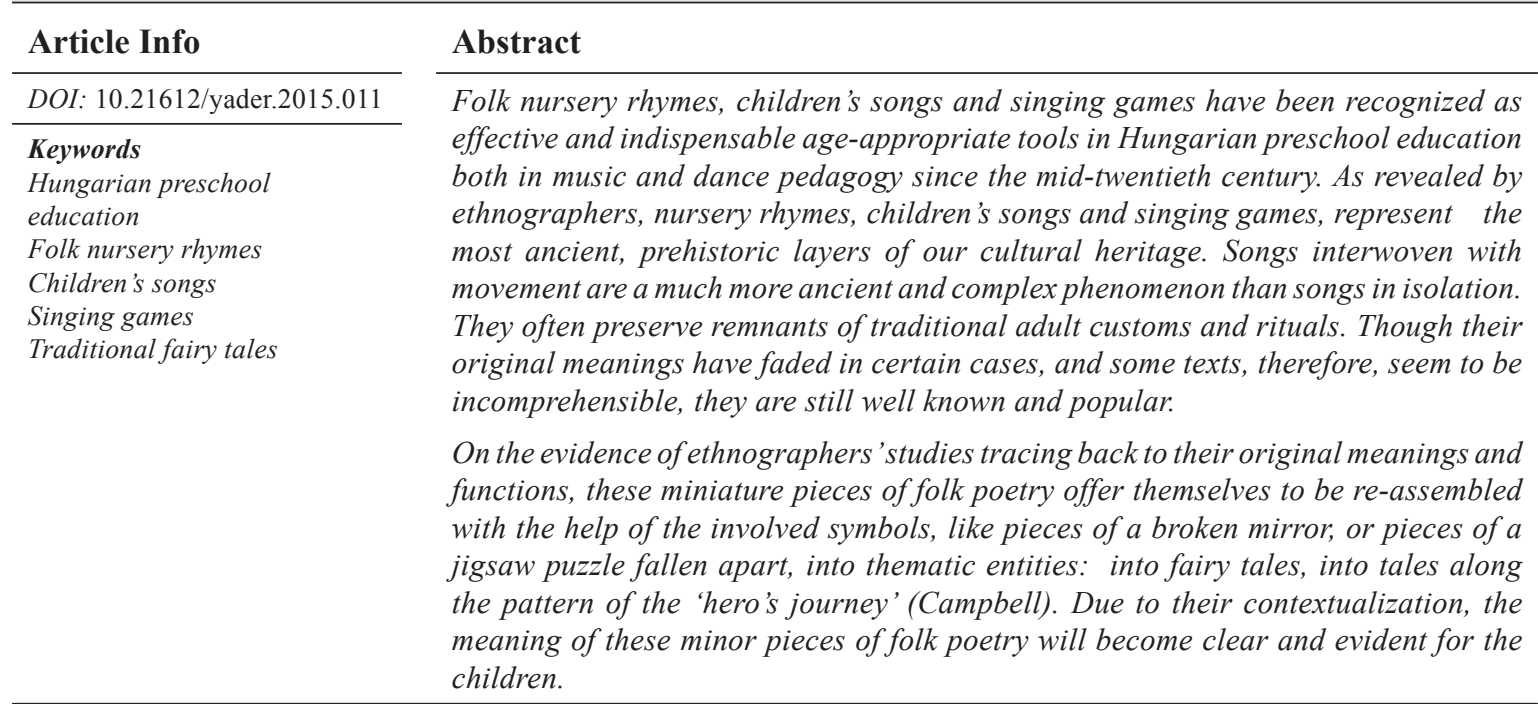

Hungarian Language Strategy Institute, Eposta: korztamas@gmail.com 


\section{Giriş}

Geleneksel çocuk tekerlemeleri, çocuk şarkıları ve şarkılı oyunlar yirminci yüzyılın ortalarından beri Macar okul öncesi eğitiminde, müzikte ve dans pedagojisinde etkili, vazgeçilmez ve yaşa uygun araçlar olarak kullanılmaktadır. Çocuk tekerlemelerinin, çocuk şarkıların ve şarkılı oyunların çok eskilere dayandığı ve tarih öncesi kültürel mirasın bir katmanı olduğu etnograflar tarafından ortaya çıkarılmıştır. Hareketlerle iç içe geçmiş şarkılar, izole olmuş hareketlerden arınmış olan şarkılardan çok daha karmaşık ve eski fenomenlerdir. Bunları sık sık geleneksel yetişkin ritüellerinde ve örflerinde görürüz. Orijinal anlamlarıyla birlikte belirli olaylarda, bazı metinlerde karşımıza çıkarlar. Bu yüzden anlaşılmaz gibi görünürler ancak hâlâ oldukça iyi bilinirler ve popülerlerdir.

Etnografların çalışmalarının kanıtlarına dayanarak bu tekerleme ve şarkılı oyunların kökenini bulmak için izleri sürülüp orijinal anlamlarına ve işlevlerine ulaşılabilir. Halk şiirinin bu küçük ürünleri birkaç kırık ayna parçası, birkaç tane dağılmış puzzle parçası gibi girift sembollerle ya da masalların içine girerek ve masallarla örülü bir hikâye olan Campbell'ın "Kahramanın Sonsuz Yolculuğu” kitabı gibi tematik şeylerle yeniden kurulup anlamlandırılabilir. Bağlamlanabilme özelliklerinden ötürü halk şiirinin bu küçük ürünleri daha yalınlaştırılarak çocuklar için daha anlaşılabilir hale getirilebilir.

Çocuk tekerlemelerinin, şarkılarının, oyunlarının ve masallarının söz konusu senteziyle masaldaki yerlerin ve kahramanların basit bir şekilde canlandırılması yapılabilir. Uygun çocuk tekerlemeleri ve şarkılarından çocuklar için yapılan yaratıcı drama çalışmalarında, psikolojide, masal terapisinde, çocuklar için yapılan psiko-drama uygulamalarında, çocuk masallarına ve oyun yaklaşımlarına anlambilimsel bir bakışla yapılacak olan veya bunların sembolik içerikleri üzerine yapılacak olan uygulamalarda etkili bir şekilde yararlanılabilir. Bu küçük ürünün yardımıyla halk masalları etkili ve kolay bir şekilde yeniden oynanarak toparlanıp bir araya getirilebilir. Bahsedilen bu model çocuklara kendilerini büyülü bir dünyadaymış gibi düşünme imkânı sunar ve onların dil ile iletişim kurmadan önce dans ederek ve şarkı söyleyerek dramatik öz-sunumlarla kendilerini açıklamalarına yardımcı olur ve böylece çocukların kendilerine yönelik farkındalıkları, öz saygıları ve diğerlerine yaklaşımları olumlu yönde gelişme gösterir. Bir topluluk içinde oyuna ve dansa aktif katılım, çocukların dengeyi sağlaması ve bütünleşik gelişimleri için zorunludur ve çocukların fiziksel, duygusal, bilişsel ve sosyal olarak olgunlaşmalarına yardım eder. Bu model; çocuk tekerlemelerinde, şarkılarında ve oyunlarında anlamın yeniden yapılandırılması ve bağlamlandırılmasıyla kültürel ve dilsel geleneğin devam etmesi ve korunması için de önemli bir rol oynamaktadır.

Çocuk tekerlemelerinin ve şarkılı oyunların Macar müziğinde, dans pedagojisinde ve okulöncesi eğitimdeki önemi

Geleneksel çocuk tekerlemeleri, çocuk şarkıları ve şarkılı oyunlar yirminci yüzyılın ortalarından beri Macar okul öncesi eğitiminde, müzikte ve dans pedagojisinde etkili, vazgeçilmez ve yaşa uygun araçlar olarak kullanılmaktadır. 


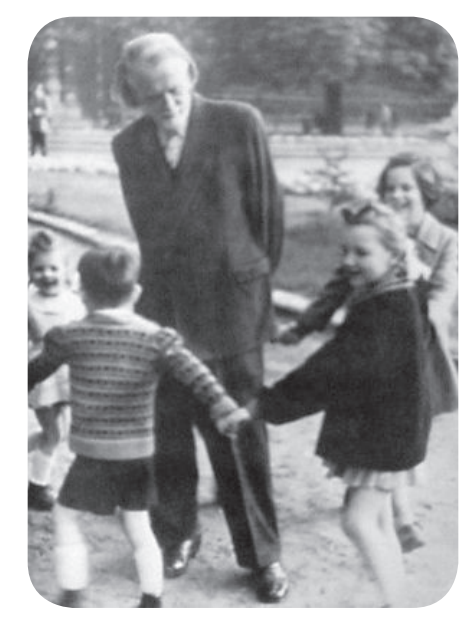

Fotoğraf 1. Zoltán Kodály (1882-1967)

Müzik pedagojisinde Kodály Yöntemi -aynı zamanda Kodály yaklaşımı olarak da adlandırılırMacar besteci ve etno-müzikolog Kodály’nin, meslektaşı halk şarkıları derleyicisi Béla Bartók ile birlikte geliştirmiş olduğu müzik eğitimi alanında eskiden beri uluslararası bilinirliğe sahip olan bir yaklaşımdır. Kodály’nin eğitim felsefesi, halk müziğini anadil olarak kullanılmasına dayanır. Çocuklar müziksel ve harekete dayalı şekilleri anadillerini öğrendikleri kadar kolay öğrenebilirler. İlk kapsamlı ve her şeyi içeren "Macar Halk Müziğì" kitabı, özellikle müziğe ve çocuk oyunlara adanmıştır. Bu yöntem Kodály ve arkadaşları tarafından birkaç yılda hazırlanmış, pedagojik ve eğitimsel çerçevesi altı-üç yaş arası okul öncesi çocukları için planlanmış ve öğrencisi Katalin Forrai tarafından genişletilmiştir.

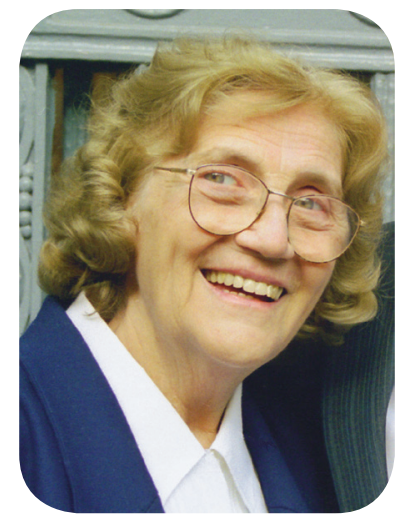

Fotoğraf 2. Katalin Forrai (1926-2004)

\section{Müzik ve Dans Eğitiminde Yaşa Uygun Standartlar}

Okul öncesi yaş dönemi çocukları için en önemli aktivite olan oyun oynamayla, Forrai’nin yaşa uygun gelişimsel okul öncesi müfredatı ve materyalleri, sözlü gelenekte yüzyıllardır nesilden nesile aktarılarak gelişen geleneksel tekerlemelerde ve yerel şarkılı oyunlarda bulunan doğal bir şekilde meydana gelen basit melodik motiflere dayanmaktadır. Bu motifler kısa formları, sekiz nota ve bir çeyreğin tamamından oluşan ikili ölçülere (2/4 ya da 6/8) sahip basit ritimleri, sınırlı altı nota aralığında beş sesli melodileri ve basit dillere sahip olmaları nedeniyle erken yaş müzik eğitimi için oldukça uygun araçlardır. Şarkılı oyunlarda şarkı söylemek ve hareket etmek bütünleşmiştir. Şarkı söyleme ve hareket etme uyumunu korumak için şarkı söylemek hiçbir zaman hareketten ayrılamaz. 
Okul öncesi dönemde şarkı söyleme ve dans etme becerilerinin gelişimi çocuğun taklit etme duygusundan ortaya çıkar. Bu yüzden öğretmen keyif alarak, net ve doğru telaffuz ve iyi tonlamayla şarkı söyleyerek çocuklara iyi bir model olmalıdır.

Forrai'nin gelişimsel okul öncesi yöntemine göre oyunların temel eğitimsel değeri; eğlencenin paylaşımında, oyunlar yoluyla ortaya çıkan doğal grup olma hissinde, oyunun ve grup deneyiminin zevkiyle eğlenerek şarkı söylemenin altında yatar. Bu yüzden ses yükseklik düzeyinin seçiminde melodik motifler ve oyun formatı çocuk gelişimi yaklaşımıyla kullanılmalıdır. Sunumlar ve icralardaki vuruş, ritim ve melodi; tempo ve motifsel yapı, çocukların kapasitelerine uygun olarak düşünülmelidir. Öğretmen üç, dört ve beş yaş grubu çocuklarının gelişim özelliklerini bilmeli ve çocukların algı seviyelerine, sosyal ve fiziksel becerilerine uygun oyunlar seçmelidir.

Üç yaş grubu çocukları kelimeleri her zaman oldukları anlamlarılla anlarlar, bu yüzden vücut dili bu yaş grubunda oldukça önemlidir. Güven veren ve sevecen bir yetişkinin varlığ onların kendilerini güvende hissetmesi için gereklidir. Üç yaş grubu çocuklarında tekerlemeler ve oyunlar bir yetişkinin çocuklarla birlikte oynayabileceği, sarılma oyunları ile bir çemberde oturma ve kalkma içeren oyunlar olarak seçilmelidir. Böylece ritim sesleri hareketler vasıtasıyla basit rol oyunlarıyla ve oyunbaz bir şekilde taklit ederek çocuk tarafindan deneyimlenebilir.

Dört yaş grubu çocukları daha sosyaldir ve oyunlar ile şarkılara katılmaktan keyif alırlar. Algıları daha hızlıdır ve odaklanma süreleri daha uzundur. Hareketlerinden daha eminlerdir, hali hazırda bir çember içinde yürürlerken bir diğerine uyum sağlayabilirler. Onlarla yapılan çember oyunlarında daha komplike hareketler (alkışlamak, yön değiştirmek, belirli bir patikada yürümek) ve spiral gibi daha komplike formlar olabilir. Yürümek, ritmi hissetmek için oldukça kullanışlıdır. Ritmi gerçekleştirmek için ise vurma ve alkışlama hareketleri oldukça kullanışlıdır.

Beş yaş grubu çocukları kendine güveni olan, cesur ve daha yaratıcı çocuklardır. Ritmi, yürürken veya sessizce hareket ederken bile hissedebilirler. Daha komplike hareketlerle (daha uzun sıralar, birkaç patikası olan sıralar, çift çember, değişen patikalar gibi) ve daha fazla karakterle oyun oynayabilme becerilerine sahiptirler. Bir tempoyu sürdürebilir veya değiştirebilirler.

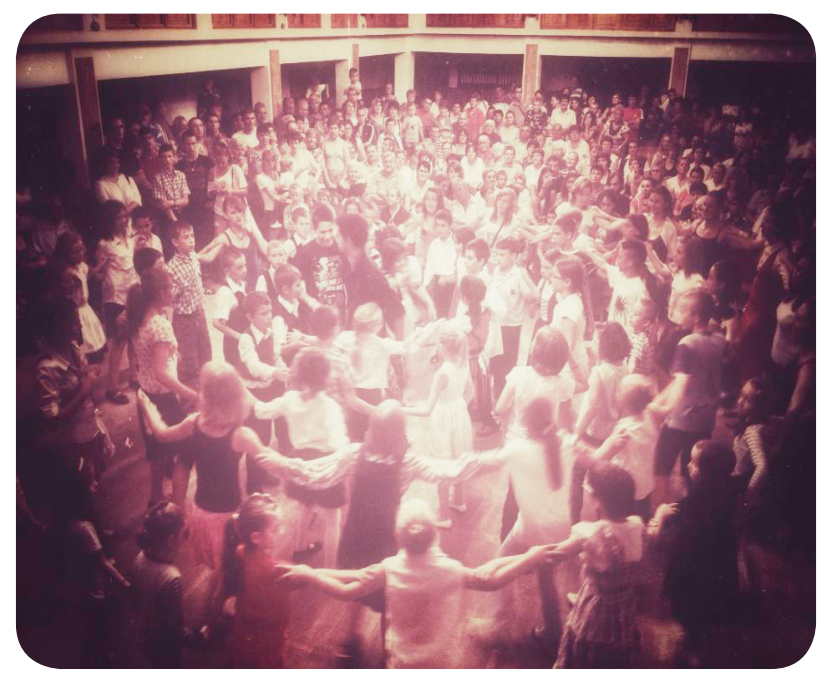

Fotoğraf 3. 2013 'te 2. Zabola Dans Kampi'nda sahnelenen The Herd Looking for his Sheep (Çoban Koyununu Arıyor) isimli çocukların yaratıcı drama performanslarının seyircilerle birlikte olan finalinde sprial formlu Transylvanian Gyimes Csángó zincir dansı /héjszal görülmektedir. 
Forrai bu oyunlar hakkında ya da orijinal olarak yetişkinlerin oynadığı basitleştirilmiş çocuk dansları hakkında, okul öncesi çocuklarından yetişkinlerin yapabildiği gibi mükemmel incelikler beklememek gerektiği konusunda uyarmaktadır. Zor basamakları/adımları öğrenmek oyun oynama ruhundan çok fazla şey götürebilir. Çocuk oyunlarında daha yer hareketleri ve adımlar içeren basit dans benzeri hareketlerle yetinilmelidir.

Erken dönem yaşa uygun dans eğitimi standartları Forrai'nin yöntemine dayanmaktadır ve benzer bir şekilde ritim, metin, hareket ve müzik birliğini vurgulamaktadır. Bu standartlar Macar Táncház Metodu’nu bulan dans pedagogu ve koreograf Jolán Foltin $(1989,2007)$ ve dans pedagogu Sándor Tímár (1999) ve onların arkadaşları ile öğrencileri tarafından genişletilmiştir. Macar Táncház Metodu, 2011'de UNESCO'nun "En İyi Korunan Uygulamalar (Best Safeguarding Practices)" listesine soyut kültürel mirasın yayılması için seçilen Macar bir dans modelidir.

\section{Masallar Bağlamında Şarkılı Çocuk Oyunlarının ve Geleneksel Çocuk Şarkılarının Anlambilimsel Yeniden Yapılandırılması}

Çocuk tekerlemelerinin, çocuk şarkıların ve şarkılı oyunların çok eskilere dayandığı ve tarih öncesi kültürel mirasımızın bir katmanı olduğu etnograflar tarafından ortaya çıkarılmıştır. Hareketlerle iç içe geçmiş şarkılar, izole olmuş hareketlerden arınmış olan şarkılardan çok daha karmaşık ve eski fenomenlerdir (Kodály 1951, XIV). Bu şarkılar, tekerlemeler ve şarkılı oyunlar genellikle yetişkin geleneklerinden, kötü ruhları kovmak veya bereket getirmek için yapılan dini ayinlerden, mevsimlere ya da hayatın dönüm noktalarına değinen ritüellerden izler taşırlar ve onları nesilden nesile aktararak korurlar. Orijinal anlamları belirli metin ve olaylarda ortaya çıktığı için anlaşılmaz gibi görünürler. Macar geleneksel çocuk şarkılarının daha genç nesillere aktarılmasında ve korunmasında Katalin Forrai'nin 1953-1988 y1lları arasında oldukça popüler olan okul öncesi çocukları için yaptığı radyo programlarının katkısı vardır ve bu şarkılar bugün bile hâlâ popüler olup iyi bilinmektedirler.

Etnografların çalışmalarının kanıtlarına dayanarak bu tekerleme ve şarkılı oyunların kökenini bulmak için izlerini sürülüp orijinal anlamlarına ve işlevlerine ulaşılabilir (Bali, 2012). Halk şiirinin bu küçük ürünleri masallarla örülü bir hikâye olan Campbell'ın "Kahramanın Sonsuz Yolculuğu” kitabı gibi tematik şeylerle yeniden kurulup anlamlandırılabilir. Bu şekilde halk şiirinin bu küçük ürünlerinin altında yatan anlambilimsel katmanlara ulaşılır ve anlambilimsel olarak daha net ve kesin hale getirilebilirler.

Kültürün geleneksel ürünleri; mitsel dairesel ahenkle, mutluluk temelinde, organik dünya görüşü ve bütünsel evren ile ilgili sembollerin uygun kod sistemine göre aktarılması ve korunmasını sağlar (Tánczos, 2007, s.394). Geleneksel folklorla korunan bu arkaik kod sisteminin sembolleri, modern dünyanın insanları tarafından gittikçe daha zor anlaşılmaya başlanmış, hatta kodlarının çözülmesi ve anlaşılması neredeyse imkânsız hale gelmeye başlamıştır. Bu yüzden bunlar aşama aşama parçalara ayrılmış ve sonunda unutulmuştur. Yine de bu kültürel kodların değerli bir hazine gibi bilinçli bir şekilde korunmasıyla yabancılaşmış insan ve atomlarına ayrılmış toplum, postmodern felsefe tarafından göz ardı edilen evreninin oluşumuna dair mükemmel hikâyeye, kayıp ahenge, güven sağlamak için güvenmeye, doğal ve organik değer sistemine ve evren tarafindan sunulan doğal ve bütüncül ahlak kurallarına giden yolu bulabilir (Harangozó, 2014, s.80).

Halk bilimi uzmanlarının belirttiği gibi aynı tarihi katmandaki halk şiiri türleri aynı uygunlukta bir dünya görüşü yansıtır. Bu geleneksel aynı uygunluktaki semboller sistemine 
dayanarak, bahsedilen halk şiiri türleri birkaç kırık ayna parçası, birkaç tane dağılmış puzzle parçası gibi girift sembollerle yeniden kurgulanabilir. Kültür ürünlerinin masallar bağlamında yeniden yapılandırılmış sentezi absürt gibi görünse de çocuk şarkılarının ve şarkılı oyunlarının "anlamsız" sözleri daha önce uzman etnografların çalışmalarında belirtildiği gibi orijinal anlamlarına yeniden kavuşabilir. Bu anlamlandırma yöntemiyle birlikte semboller çözülmeden anlamları apaçık biçimde yeniden açıklığa kavuşturulabilir ve yeniden yorumlanabilir. Böylece masallarla halk şiirinin bu küçük ürünlerinin anlamı çocuklar için daha açık ve anlaşı1ır hale gelecektir.

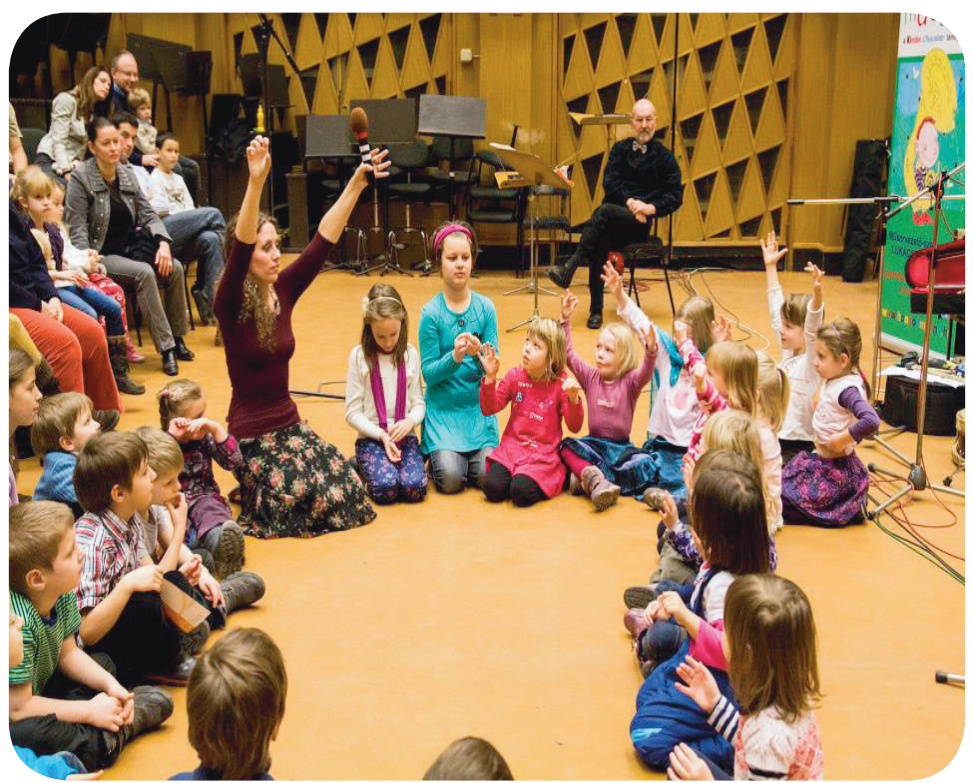

Etnografik çalışmalara dayanarak masallar bağlamında şarkılı çocuk oyunlarının ve geleneksel çocuk şarkılarının anlambilimsel yeniden yapılandırılması, çocuk psikologu Klára Korzenszky (2012) tarafindan çocuklarla yapılan yaratıcı drama programı olan Szerelemcsütörtök dobszerda2 (Tatlı Perşembe, Tıkırdayan Çarşamba) ile uygulanmaya başlanmıştır. Klára'nın CD’si Macaristan'da çocuklar için hazırlanan belki de en doğru folklor temelli derleme olma özelliğini taşır (Bali, 2012).

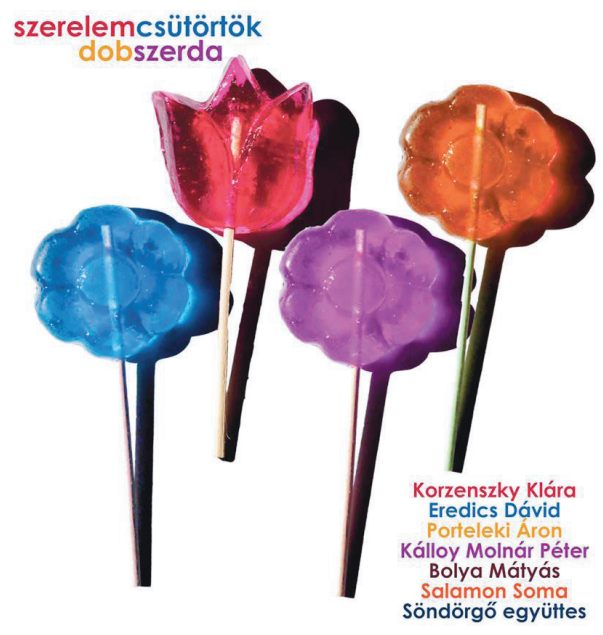

Fotoğraf 4. CD

2 Ters bir sırayla haftanın üç gününü belirten (Cuma, Perşembe, Çarşamba) şarkılı bir oyunun nakaratı. 
Macar masalları, biçimsel olarak Joseph Campbell'in "Kahramanın Sonsuz Yolculuğu" nun biçimini takip eder. "Bir kahraman, doğaüstü bir harikalar diyarında sıradan bir günde kendini tehlikeye atar; orada efsanevi güçlerle karşılaşır ve şüphesiz bir şekilde bu karşılaşmayı kazanır. Kahraman gizemli yolculuğunu bitirir ve geri döndüğünde onun ardılı olacak başka bir kahramana tüm gücünü bağışlar (Campbell, 1949, s.23). Tek başına ya da yanında yardımcı olan birileri varken çok şiddetli zorluklar, görevler ve sorumluluklarla karşılaşır ve sonunda belki de dünyaya barış ve mutluluk getirecek bir hediye kazanır.

Yaratıcı dramada veya interaktif konser performanslarında masalın ana karakterleri (prens, prenses, yardımcılar, mitolojik demir ustaları veya sihirli atlar, ejderhalar, periler) belli mekânlarda (saray, ev, çayır, orman, bahçe, kilise) ve belli durumlarda (presesi ejderhanın elinden kurtarmak, yer altı dünyasında tutsaklık, ejderhayla kavga, evlenme, nişanlanma, düğün) basit ve uygun tekerlemeler, şark1lar veya oyunlarla sunulabilirler. Bu malzemeleri derlerken Klára Gazda (2000, 2003), Marcell Jankovics (1996), István Szőcs (1972), Imola Küllős (1980), Zoltán Móser (1997), Károly Falvay (2001)'in halk bilimi çalışmalarından yararlanılabilir.

\section{Okul Öncesi Gelişimde Halk Tekerlemeleri ve Şarkılı Oyunlarından Bağlam İçinde Daha İleri Yararlanma}

Tekerlemelerin, şarkıların, oyunların ve masalların kahramanlarının basit bir şekilde uygun müzik ve şarkılarla sunulduğu bu sentezden; psikolojide Bettelheim'ın "The Uses of Enchantment: The Meaning and Importance of Fairy Tales" (Büyünün Kullanımları: Masalların Önemi ve Anlamı) kitabını, masal terapisinde Boldizsár'ın, çocuk psiko-dramasında Kende'nin, çocuk yaratıcı dramasında Gabnai'nin, oyunların ve masalların sembolik içerikleri ve anlamsal boyutları üzerine çalışmalar yapan Slade'in izlerini takip ederek başarılı bir şekilde yararlanılabilir. Onlar yaşamın öz kaynağını, insan içgüdülerinin noksanlığını, evrensel problemleri imsel terimlerle aramada çocuklar için olan masalların duygusal ve sembolik önemi üzerinde durmuşlardır. İyimserlikleriyle ve karanlı̆̆ kovan ışıklarıyla, iyinin kötü karşısında kazanmasıyla, zorluklarla mücadele edip galip gelerek bir masalda kazanan kahramanlar çocuklara sadece ahlak değerleri aktarımını sağlanmaz aynı zamanda çocuklar için dünyayla baş etmede ve yaşamın zorluklarının üstesinden gelmede kullanışlı bir rehber görevi görürler.

Bu küçük türlerin yardımıyla masallar kolay ve özellikle de çekici bir yolla yeniden oynanabilir ve yeniden toplanabilirler. Tekerlemeler, oyunlar, halk şarkıları ve masallar vasıtasıyla benzer hikâyeler anımsanıp, yeniden oynatılıp yeniden anlatılabilir. Bu model, çocuklara kendilerini büyülü bir dünyadaymış gibi düşünme imkânı sunar ve onların dil ile iletişim kurmadan önce dans ederek ve şarkı söyleyerek dramatik öz-sunumlarla kendilerini açıklamalarına yardımcı olur ve böylece çocukların kendilerine yönelik farkındalıkları, öz saygıları ve diğerlerine yaklaşımları olumlu yönde gelişme gösterir. Masal, iplerden örülen bu sihir, doğanın düzeninden gelen bir dünya imajı sunar ve bize güvende olma duygusunu arz eder. Dans ederek ve şarkı söyleyerek beynin her iki yarım küresine de hitap eden devinduyumsal yaklaşımla bu yaratıcı oyun (Kun, 2012) sadece çocukların hayal güçlerini geliştirme ve kendilerini ifade etmelerinde onları cesaretlendirmez, aynı zamanda da ince ve kaba motor becerilerini de geliştirir. Topluluğa aktif katılım; fiziksel, duygusal, bilişsel ve sosyal olarak çocukların olgunlaşmasını sağlar. Çocuk şarkıları ve yaratıcı dramanın masalsı dünyasının oyunları, şarkılı oyunlarla birlikte çocuklara duygusal olarak güç durumlarla başa çıkmada hatırı sayılır bir destek verirler ve zorluklarla baş etmelerinde ve gelişimlerinde bir terapi olabilirler. 


\section{Kültürel Tekerlemelerin, Çocuk Şarkılarının ve Şarkılı Oyunların Kültürel ve Dilsel Geleneği Sürdürme ve Korumadaki Önemi}

Macar tekerlemeleri, çocuk şarkılarının ve şarkılı oyunların yukarıda da bahsedildiği gibi kültürel mirasın en eski, tarih öncesi katmanlarını sunarlar ve ayrıca kültürel mirası koruma noktasında da yüksek derecede öneme sahiptirler. Ayrıca UNESCO’nun “2015 Uluslararası Anadil Günü”nde belirttiği gibi: "Diller bizim soyut ve somut mirasımızı geliştiren ve koruyan en önemli araçlarımızdır. Anadillerin yayılımını geliştirmek için yapılan her eylem sadece çok dilli eğitimi ve dilsel çeşitliliği artıcı olmaz aynı zamanda da dilsel ve kültürel geleneklerin dünya çapında yayılmasını ve anlaşma, tolerans ve diyaloga dayalı dayanışma ruhunun daha fazla gelişmesini sağlar" (UNESCO, 2015).

UNESCO'nun genel müdürü Bayan İrina Bokova'nın 21 Şubat 2015'te o gün dair verdiği mesaj1 şu şekildedir: "Uluslararası Anadil Günü hepimizin tüm eğitimsel çabalarla, öğrenme kalitesini artırmak ve ulaşılmayanlara ulaşmak için anadilin önemini için hepimizin hep birlikte kaldırdı ̆̆ bir bayră̆ın olduğu andır” (Bakova, 2015).

\section{Kaynakça}

Bali, J. (2012). Gondolatok Korzenszky Klára: Szerelemcsütörtök, dobszerda c. CD-je (FolkEurópa Kiadó, 2012) kapcsán. http://folkradio.hu/hir/5718

Bettelheim, B. (1976). The uses of enchantment. The meaning and importance of fairy tales random house. New York, 1976.

Bokova, I. (2015). Message from Ms Irina Bokova, Director-General of UNESCO on the occasion on 21 February $2015 \mathrm{http} / /$ unesdoc.unesco.org/images/0023/002316/231624E.pdf

Boldizsár, I. (2010). Meseterápia(Tale Therapy). Magvető, Budapest.

Budainé Balatoni Katalin: Így tedd rá! + CD - Táncos mozgásfejlesztés az óvodában óvó- és táncpedagógusok részére. Ráckeve.

Campbell, J. (1949). The hero with a thousand faces. Princeton: Princeton University Press.

Chosky 1999 Choksy, Lois. The Kodály Method I: Comprehensive Music Education. Upper Saddle River, New Jersey: Prentice-Hall, 1999, 2.

Csapody,K., Akinek a verse divatos.Varró Dániel: Akinek a lába hatos. ' Bárka, XIX 2011/5, 108-110. http:// www.barkaonline.hu/tarca/2347-varro-daniel-koeteterl

Falvay, K. (2001). Boldogasszony - A nöi szerep a magyar hitvilág tükrében. Tertia.

Foltin, J. (1989). Szállj elő zöldág (Játék és tánc gyermekeknek I.) Országos Közműv. Központ, Atticus, Budapest.

Foltin J. \&Tarján, T. K. (2007). Játék és tánc gyermekeknek . Hagyományok Háza Budapest.

Forrai, K.(1988). Forrai, Katalin: Music in Preschool. Translated and adapted by Jean Sinor. Corvina Budpaest.

Gabnai, K. (2011). Drámajátékok. Bevezetés a drámapedagógiába. Helikon, Budapest.

Gazda, K.(2000). A magyar hintázási hagyományok összehasonlító perspektívából. Erdélyi Múzeum. LXII. Évf, 3-4. 193-236

Gazda, K.(2003). Isten kovácsa. In: Szikszai Mária (ed.): Kriza János Néprajzi Társaság Évkönyve 11. Játék és kultúra. Kriza János Néprajzi Társaság. Kolozsvár, 9-48

Harangozó, I. (2014). Maczóné Káplár Zsófia : Elmulasztott utak, megtalált ösvények. Beszélgetés Harangozó Imre néprajzkutatóval. Frig Kiadó.

Jankovics, M.( 1996). Árgirus csillagai. In: Ahol a madár se jár. Pontifex, 72-83. 
Kende B. H. (2003).Gyermekpszichodráma, (Child Psychordama), Budapest: Osiris

Kodály, Z. (1951). Preface by Zoltán Kodály to A magyar népzene tára : Corpus musicae popularis Hungaricae / Hungarian Folk Music/ ed. Béla Bartók and Zoltán Kodály. Vol. 1. Gyermekjátékok/ Children’s Games ed. György Kerényi, Budapest: Akadémiai

Korzenszky, K.(2012). Szerelemcsütörtök, dobszerda c. CD (FolkEurópa Kiadó.

Kun, K. (2012). Alapkészségek fejlesztési lehetősége a népi játékok és a néptánc tanításával. Tudásmenedzsment a Pécsi Tudományegyetem Felnőttképzési és Emberi Erőforrás Fejlesztési Karának periodikája, XIII /1, 2012. április, 88-97., http://www.kenderke.hu/hu/673

http://old.feek.pte.hu/tudasmenedzsment/cikkek/131szam_11-kun.pdf

Küllős, I. (1980). Csillag Boris. Egy gyermekjátékdal szövegelemzése. In: Szemerkényi Ágnes (szerk.) Nógrádsipek. Tanulmányok egy észak-magyarországi falu mai folklórjáról. Akadémiai, Bp.

Móser, Z. (1997). Síppal, dobbal és /nádi/hegedűvel. Álmodik a múlt. Pro-Print, Csíkszereda-Székesfehérvár, 24-38.).

Slade, P. (1954). Child drama. University of London Press,

Szöcs, I. (1972). Halandzsa-e az Antanténusz? Utunk, Kolozsvár.2-4

Tánczos, V.(2007). Szimbolikus formák a folklórban. Kairosz, Bp.

Tímár, S. (1999). Néptáncnyelven. Püski. Budapest.

UNESCO (2015). International Mother Language Day.

http://www.un.org/en/events/motherlanguageday/ 





\section{Singing and Dance as Our Mother Tongue; Traditional Nursery Rhymes and Singing Games in Preschool Fairy Tale Drama}

\section{Tamás Korzenszky}

Folk nursery rhymes, children's songs and singing games have been recognized as effective and indispensable age-appropriate tools in Hungarian preschool education both in music and dance pedagogy since the mid-twentieth century. As revealed by ethnographers, nursery rhymes, children's songs and singing games, represent the most ancient, prehistoric layers of our cultural heritage. Songs intervowen with movement are a much more ancient and complex phenomenon than songs in isolation. They often preserve remnants of traditional adult customs and rituals. Though their original meanings have faded in certain cases, and some texts, therefore, seem to be incomprehensible, they are still well known and popular.

On the evidence of ethnographers' studies tracing back to their original meanings and functions, these miniature pieces of folk poetry offer themselves to be re-assembled with the help of the involved symbols, like pieces of a broken mirror, or pieces of a jigsaw puzzle fallen apart, into thematic entities: into fairy tales, into tales along the pattern of the 'hero's journey' (Campbell). Due to their contextualization, the meaning of these minor pieces of folk poetry will become clear and evident for the children.

This synthesis of nursery rhymes, songs, games and fairy tales, where tale situations and heroes can be represented by simple, appropriate nursery rhymes or songs, can be successfully exploited by infant creative drama, psychology, tale therapy and infant psychodrama practice, approaching games and fairy tales from from the semantic side, from their symbolic contents. With the help of these minor genres, fairy tales can be recollected and re-played in an easy and especially attractive way. This model offers children the possibility of projecting themselves into a magical world and to express themselves emotionally through dramatic self- presentation with singing and 'dance' before they possess command over language, in order to increase self-awareness, self-esteem and appreciation of others. Active participation in game and dancing in the community, indispensable from the point of view of the children's balanced and integrated development, helps children mature physically, emotionally, cognitively and socially. Through the contextualization and reconstruction of the semantics of nursery rhymes, songs and games, this model can also play and important role in safeguarding the continuity of our linguistic and cultural tradition.

The İmportance of Nursery Rhymes and Singing Games in Hungarian Music and Dance Pedagogy in Preschool Education

Traditional nursery rhymes and singing games have been recognized as effective and indispensable age-appropriate tools in Hungarian preschool education both in music and dance pedagogy since the mid twentieth century. 


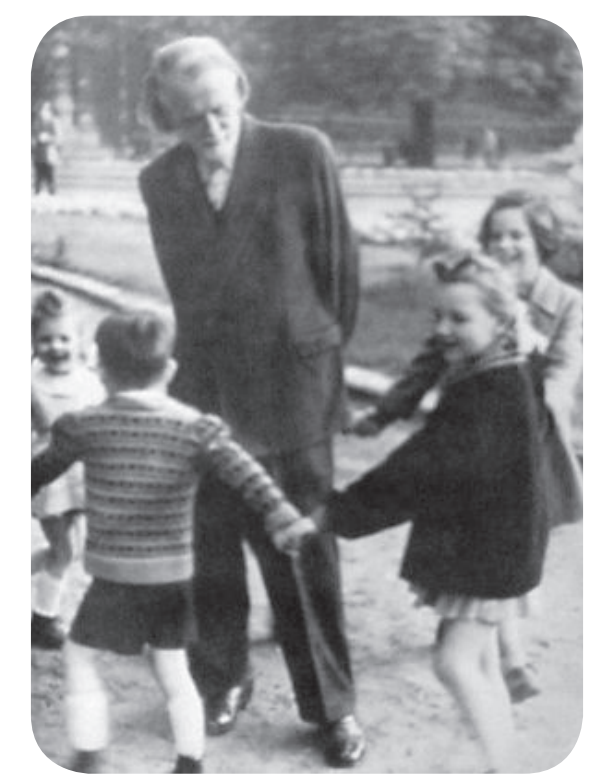

Photo 1. Zoltán Kodály (1882-1967)

In music pedagogy, the Kodály Method, also referred to as the Kodály Concept, is an internationally recognized approach to music education from the early age, developed by Hungarian composer and ethnomusicologist Zoltán Kodály (1882-1967), collector of folk songs along with his colleague Béla Bartók. Kodály's philosophy of education was based on the folk music as our mother tongue. Children learn musical and movement patterns as readily as readily as they learn language. The entire first volume of the monumental collection Hungarian Folk Music is devoted exclusively to the music and games of children (Kodály, 1951). The methodology was developed over a number of years by Kodály's associates: the overall pedagogical and didactic framework devised for children of the kindergarten age between three and six was elaborated by his pupil Katalin Forrai.

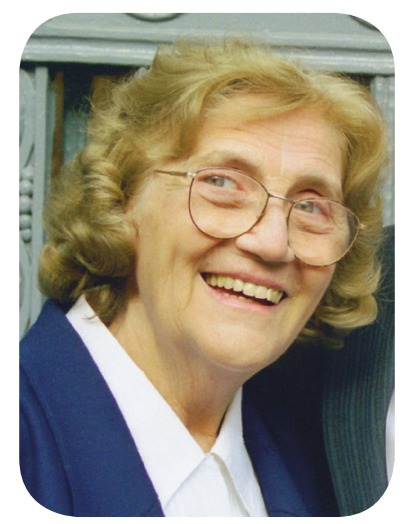

Photo 2. Katalin Forrai (1926-2004)

\section{Age-Appropriate Standards in Music and Dance Education}

With playing regarded as the most important activity for children of the kindergarten age (58), Forrai's age-appropriate progressive preschool curriculum and material are based on the naturally occurring, simple melodic motives found in rural singing games and traditional rhymes, developed and handed down for centuries in the oral tradition (Forrai, 1988). They an ideal vehicle 
for early musical training because of their short forms, their simple rhythms in duple meter $(2 / 4$ or 6/8) consisting entirely of quarters and eighth notes, their simple pentatonic melodies within a limited, six-note range and their simple language (Chosky 1999, p. 2). In singing games singing and movement are an integrated whole. In order to preserve the unity of song and movement, singing should never be separated from movement.

The development of singing and dancing skills in the kindergarten grows out of the child's desire to imitate. Therefore, the teacher should provide a good model by singing with good intonation, exact articulation, correct pronunciation and obvious pleasure.

According to Forrai's progressive preschool methodology the "main pedagogical value of games lies in the shared enjoyment and natural group feeling they create ... the joy of singing, the pleasure of the game and the group experience.", therefore in the selection of the pitch range, the melodic motives and the game format a child developmental approach is used, introducing skills and practicing regular beat, rhythm and melody, tempo and motivic structure in accordance with the capabilities of the child.

The teacher must know the particular developmental characteristics of the age groups three, four and five, and choose games commensurate with the children's level of perception and their social and phsycal skills.

3-year-olds not always understand the exact meaning of the words, therefore body language is very important to them. The presence of a confident and loving adult is necessary for them to feel secure. With three-year olds you should choose rhymes and games which an adult can play with the children, lap games and games which involve standing or sitting in a circle so that regular beat can be experienced through movements done while the child remains in the spot, with playful imitative movements and simple role games.

4-year olds are more social, they enjoy taking part in games and singing. Their perception is quicker and their attention span is longer. They are surer in their movements, they can already walk in circle and adjust to one another. Their circle games can entail more complex movements (clapping, changing directions, walking with partners) and more complex formats, like spirals. Walking is particularly useful for feeling the beat, tapping or clapping to perform the rhythm.

5-year-olds are self-confident, bold and more creative. They can feel the beat even while walking or moving silently. They are able to play games with more complicated movements (longer lines, lines passing several gates, double circles, changing partners), and more characters. They can maintain or change a tempo. 


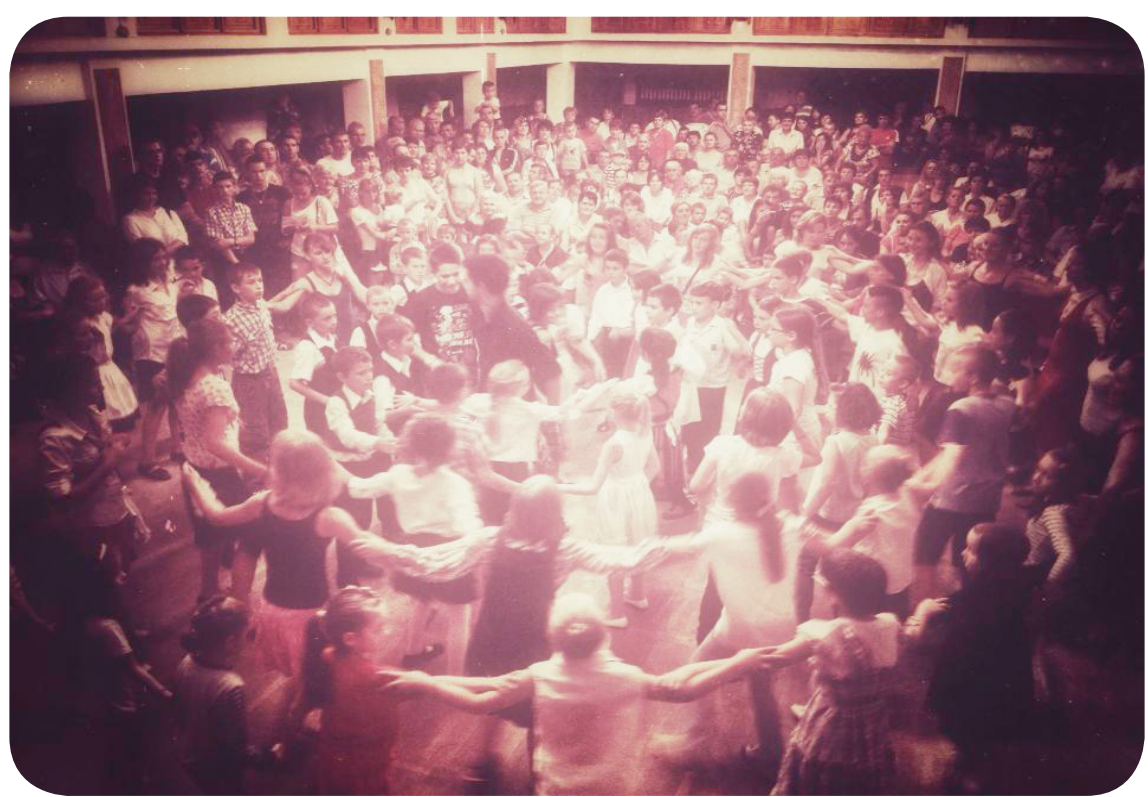

Photo 3. a spiral formed Transylvanian Gyimes Csángó chain dance /héjszal in common with the audience in the finale of a children's creative drama The Herd Looking for his Sheep performed at the 2nd Zabola Dance Camp, 2013

Forrai warned, that with these games (or simple children's dances, originally played by adolescents, you cannot expect preschool children to be able "to cope with adolescents with such wonderful grace. Learning the difficult steps would detract too much from the spirit of play... In children's games we should be content with simpler dance-like movements and less complex floor patterns."

Age-appropriate standards for early dance education based on Forrai's methodology, and similarly emphasizing the unity of rhythm, text, movement and music, were elaborated by dance pedagogue and choreographer Jolán Foltin $(1989,2007)$ a founder of the Hungarian Táncház Method, a Hungarian model for the transmission of intangible cultural heritage, selected in 2011 on the UNESCO list of Best Safeguarding Practices, and dance pedagogue Sándor Tímár (1999), their associates and pupils (Budainé, 2011).

\section{Semantic Reconstruction of Folk Nursery Rhymes and Singing Children's Games in the Context of Fairy Tales}

As revealed by ethnographers, nursery rhymes, children's songs and singing games, represent the most ancient, prehistoric layers of our cultural heritage. Songs intervowen with movement are a much more ancient and complex phenomenon than songs in isolation (Kodály 1951, XIV.) They often preserve the remnants, of traditional adult customs and rituals at tuning points of life and seasons and of ancient rites to enhance fertility or to ward off evil.

Though their original meanings have faded in certain cases, and some texts, therefore, seem to be incomprehensible, our nursery rhymes have been preserved and endorsed also by the youngest generations - Katalin Forrai's radio programmes for preschool children between 1953-1988 have a great share in their popularity and they are still well known and popular. 
On the evidence of ethnographers' studies tracing back to their original meanings and functions, these miniature pieces of folk poetry offer themselves to be contextualized (Bali, 2012), re-arranged with the help of the involved symbols into thematic entities: into fairy tales, tales along the 'hero's journey' (Campbell, 1949). This way hidden semantic layers of these minor pieces of folk poetry can be detected and their meaning will become clear and evident.

Traditional pieces of folklore preserve a consistent code system of symbols corresponding to a collective cosmic, organic worldview, based on in the happy, mythic harmony of cyclicity (Tánczos, 2007, p. 394). This archaic code system of symbols preserved by folklore is becoming more and more difficult or even impossible to be decoded by people of the modern world, therefore it may be gradually disintegrated and, in the end, completely forgotten. It, however, should be consciously safeguarded as a special treasure that can help alienated man and atomized society find back to the „Great Story” neglected by postmodern philosophy, to the lost harmony, to safe supports in a safe, natural, organic system of values and a natural. Collective ethics based on the order of the universe (Harangozó, 2014, p. 80).

As folklorists pointed out, pieces of folk poetry of the same historic layer represent the same coherent world view. On the basis of this traditional coherent system of symbols, the minor pieces of folk poetry can be reassembled along the pattern of fairy tales like pieces of a broken mirror, or pieces of a jigsaw puzzle fallen apart. In the reconstructed synthesis of folk genres in the context of fairy tales, also the seemingly absurd, 'nonsense' texts of nursery rhymes and children's singing games can re-gain their original meaning, as previously revealed by ethnographers in expert studies. By this method of contextualization, however, they can be evidently, re-interpreted", their meanings "re-elucidated", without uncoding their symbols. So, within fairy tales, the meaning of these minor pieces of folk poetry will become evident and clear also for children.

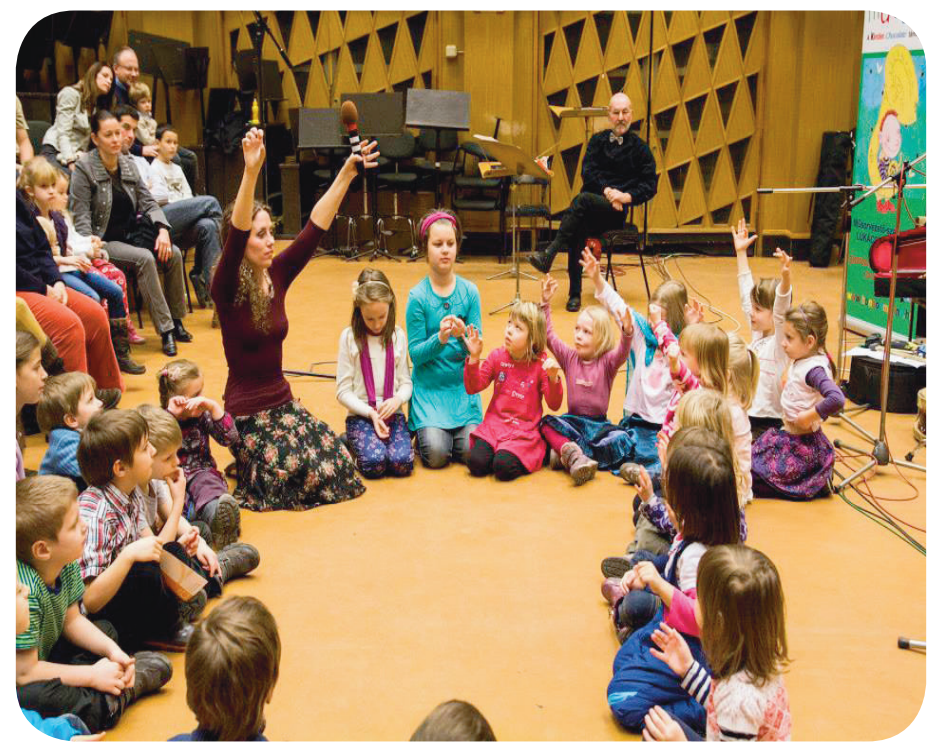

The semantic reconstruction of folk nursery rhymes and children's singing games in the context of fairy tales on the basis of ethnographic studies has been initiated by the child creative drama program Szerelemcsütörtök dobszerda (Love Thursday, Drum Wednesday) ${ }^{3}$ by child psychologist Klára Korzenszky (2012).

3 The refrain of a singing game, which mentions three days of the week in reverse order (Friday, Thursday, Wednesday). 


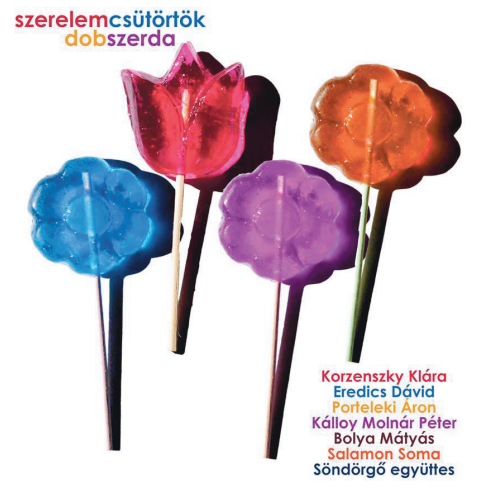

Photo 5. Klára Korzenszky's CD

Her CD has been featured as the ,perhaps most accurately compiled folklore-based CD for children in Hungary so far" (Bali 2012).

The pattern of Hungarian fairy tales usually follows the pattern of the hero's journey defined by Joseph Campbell: A hero ventures forth from the world of common day into a region of supernatural wonder: fabulous forces are there encountered and a decisive victory is won: the hero comes back from this mysterious adventure with the power to bestow boons on his fellow man"(Campbell, 1949, 23). He faces severe challenges, tasks and trials, either alone or with assistance, for which he achieves a great gift which may be used to improve the world.

In creative drama or interactive concert performances, major characters of the fairy tale (prince, princess, assistants - ie. the mythological smith or the magic horse -- dragon, fairies), scenes (palace, house, field. wood, orchard, church) and situations (rape of the princess by the dragon, captivity in the underworld, fight with the dragon, proposal, engagement, wedding) can be represented by simple, appropriate nursery rhymes, games or songs. In the compilation of the material we drew on folklore studies by Klára Gazda (2000, 2003), Marcell Jankovics (1996), István Szőcs (1972), Imola Küllős (1980), Zoltán Móser (1997), Károly Falvay (2001).

\section{Further Exploitation of Contextualized Folk Rhymes and Singing Games in Preschool}

\section{Development}

This synthesis of nursery rhymes, songs, games and fairy tales, where tale situations and heroes can be represented by simple, appropriate nursery rhymes or songs can be successfully exploited by psychology in the wake of Bettelheim's The Uses of Enchantment. The Meaning and Importance of Fairy Tales (1976), tale therapy (Boldizsár) and infant psychodrama (Kende) practice and infant creative drama (Gabnai) in the wake of Slade, approaching games and fairy tales from the semantic side, from their symbolic contents. They emphasize the emotional and symbolic importance of fairy tales for children, in explaining core life concepts, intrinsic human flaws and universal problems in symbolic terms. With their optimism, with light defeating darkness, good overcoming evil, with the protagonist overcoming hardships and winning a reward fairy tales they not only transmit moral values but also provide a useful guide for children to face life and to cope with the world.

With the help of these minor genres, fairy tales can be recollected and re-played in an easy 
and especially attractive way. Through nursery rhymes, games, folk songs and tales, a familiar story can be evoked, retold and replayed. This model offers children the possibility of projecting themselves into a magical world and to express themselves emotionally through dramatic selfpresentation before they possess command over language in order to increase self-awareness, selfesteem and appreciation of others. The magic is woven from the threads of tales that preserve an image of the world derived from the natural order, offering us all guidance and a sense of security. This kinaesthetic approach of creative play with singing and dancing involving both hemispheres (Kun, 2012) not only encourages their imagination and individual expression but also develops their fine and gross motor skills. Active participation in the community helps children mature physically, emotionally, cognitively and socially.

Nursery rhymes and games well-known from fairy tale creative dramas with singing games can hence serve for children as a considerable support in emotionally difficult situations to overcome their difficulties and they can be exploited in development and therapy.

\section{The Importance of Folk Nursery Rhymes, Singing Games and Children's Songs in Safeguarding the Continuity of Our Linguistic and Cultural Tradition}

The preservation of our nursery rhymes and singing games representing, as seen above, the most ancient, prehistoric layers of our cultural heritage, is of preeminent importance also from the point of view of the safeguarding of our cultural heritage. As also pointed out by UNESCO on the occasion of the International Mother Language Day, 2015, "Languages are the most powerful instruments of preserving and developing our tangible and intangible heritage. All moves to promote the dissemination of mother tongues will serve not only to encourage linguistic diversity and multilingual education but also to develop fuller awareness of linguistic and cultural traditions throughout the world and to inspire solidarity based on understanding, tolerance and dialogue" (UNESCO 2015).

According to the message of Message from Ms Irina Bokova, Director-General of UNESCO on the occasion on 21 February 2015, "International Mother Language Day is a moment for all of us to raise the flag for the importance of mother tongue to all educational efforts, to enhance the quality of learning and to reach the unreached"(Bokova, 2015).

\section{Bibliography}

Bali, J. (2012). Gondolatok Korzenszky Klára: Szerelemcsütörtök, dobszerda c. CD-je (FolkEurópa Kiadó, 2012) kapcsán. http://folkradio.hu/hir/5718

Bettelheim, B.(1976). The Uses of Enchantment. The Meaning and Importance of Fairy Tales Random House, New York, 1976.

Bokova, I. (2015). Message from Ms Irina Bokova, Director-General of UNESCO on the occasion on 21 February $2015 \mathrm{http}: / /$ unesdoc.unesco.org/images/0023/002316/231624E.pdf

Boldizsár, I. (2010).Meseterápia(Tale Therapy). Magvetö, Budapest.

Budainé Balatoni Katalin: Így tedd rá! + CD - Táncos mozgásfejlesztés az óvodában óvó- és táncpedagógusok részére. Ráckeve, 2011

Campbell, J.(1949). The Hero with a Thousand Faces. Princeton: Princeton University Press.

Chosky 1999 Choksy, Lois. The Kodály Method I: Comprehensive Music Education. Upper Saddle River, New Jersey: Prentice-Hall, 1999, 2) 
Csapody,K. ,Akinek a verse divatos.Varró Dániel: Akinek a lába hatos. ‘ Bárka, XIX 2011/5, 108-110. http:// www.barkaonline.hu/tarca/2347-varro-daniel-koeteterl

Falvay, K.(2001). Boldogasszony - A nöi szerep a magyar hitvilág tükrében. Tertia.

Foltin, J.(1989). Szállj elő zöldág (Játék és tánc gyermekeknek I.) Országos Közmüv. Központ, Atticus, Budapest, 1989

Foltin J.-Tarján T. K. (2007). Játék és tánc gyermekeknek . Hagyományok Háza Budapest.

Forrai, K.(1988). Forrai, Katalin: Music in Preschool. Translated and adapted by Jean Sinor. Corvina Budpaest

Gabnai, K. (2011). Drámajátékok. Bevezetés a drámapedagógiába. Helikon, Budapest.

Gazda, K.(2000). A magyar hintázási hagyományok összehasonlító perspektívából. Erdélyi Múzeum. LXII. Évf, 3-4. 193-236

Gazda, K.(2003). Isten kovácsa. In: Szikszai Mária (ed.): Kriza János Néprajzi Társaság Évkönyve 11. Játék és kultúra. Kriza János Néprajzi Társaság. Kolozsvár, 9-48

Harangozó, I. (2014). Maczóné Káplár Zsófia : Elmulasztott utak, megtalált ösvények. Beszélgetés Harangozó Imre néprajzkutatóval. Frig Kiadó.

Jankovics, M.( 1996). Árgirus csillagai. In: Ahol a madár se jár. Pontifex, 72-83.

Kende B. H. (2003).Gyermekpszichodráma, (Child Psychordama), Budapest: Osiris

Kodály, Z. (1951). Preface by Zoltán Kodály to A magyar népzene tára : Corpus musicae popularis Hungaricae / Hungarian Folk Music/ ed. Béla Bartók and Zoltán Kodály. Vol. 1. Gyermekjátékok/ Children’s Games ed. György Kerényi, Budapest: Akadémiai

Korzenszky, K.(2012). Szerelemcsütörtök, dobszerda c. CD (FolkEurópa Kiadó.

Kun, K. (2012). Alapkészségek fejlesztési lehetősége a népi játékok és a néptánc tanításával. Tudásmenedzsment a Pécsi Tudományegyetem Felnőttképzési és Emberi Erőforrás Fejlesztési Karának periodikája, XIII /1, 2012. április, 88-97., http://www.kenderke.hu/hu/673

http://old.feek.pte.hu/tudasmenedzsment/cikkek/131szam_11-kun.pdf

Küllős, I. (1980). Csillag Boris. Egy gyermekjátékdal szövegelemzése. In: Szemerkényi Ágnes (szerk.) Nógrádsipek. Tanulmányok egy észak-magyarországi falu mai folklórjáról. Akadémiai, Bp.

Móser, Z. (1997). Síppal, dobbal és /nádi/hegedűvel. Álmodik a múlt. Pro-Print, Csíkszereda-Székesfehérvár, 24-38.).

Slade, P. (1954). Child Drama. University of London Press,

Szőcs, I. (1972). Halandzsa-e az Antanténusz? Utunk, Kolozsvár.2-4

Tánczos, V.(2007): Szimbolikus formák a folklórban. Kairosz, Bp.

Tímár, S. (1999). Néptáncnyelven. Püski. Budapest.

UNESCO (2015): International Mother Language Day. http://www.un.org/en/events/motherlanguageday/ 